\title{
COVID-19 - The invisible enemy: impacts on students' mental health and coping
}

\section{strategies}

COVID-19 - O inimigo invisível: impactos na saúde mental dos estudantes e estratégias de enfrentamento

COVID-19 - El enemigo invisible: impactos em la salud mental de los estudiantes y las estrategias de afrontamiento

\author{
Ana Lúcia Basilio Carneiro \\ ORCID: https://orcid.org/0000-0003-2035-8328 \\ Universidade Federal da Paraíba, Brazil \\ E-mail: analucarneiro@gmail.com \\ Semírames Cartonilho de Souza Ramos \\ ORCID: https://orcid.org/0000-0001-8370-5994 \\ Universidade Federal da Paraíba, Brazil \\ E-mail: semiramesramosmoga@gmail.com \\ Arthur Willian de Lima Brasil \\ ORCID: https://orcid.org/0000-0002-1862-6517 \\ Universidade Federal da Paraíba, Brazil \\ E-mail:arthurwillian7@yahoo.com.br \\ Lindair Alves da Silva \\ ORCID: https://orcid.org/0000-0001-8380-3877 \\ Hospital Metropolitano Dom José Maria Pires, Brazil \\ E-mail: alveslindair@gmail.com \\ Gleydson Grangeiro de Lima \\ ORCID: https://orcid.org/0000-0001-6374-8831 \\ Universidade Federal da Paraíba, Brazil \\ E-mail: gleydsongrangeiro@gmail.com \\ Lincoln Basilio Alves \\ ORCID: https://orcid.org/0000-0001-8937-6546 \\ Universidade Federal da Paraíba, Brazil \\ E-mail: lincolnbasilio1@gmail.com \\ Mariana Nunes Azevedo de Melo \\ ORCID: https://orcid.org/0000-0003-3011-7691 \\ Universidade Federal da Paraíba, Brazil \\ E-mail: mariananadm@gmail.com \\ Conceição de Maria Bezerra de Melo \\ ORCID: https://orcid.org/0000-0003-3282-8665 \\ Universidade Federal da Paraíba, Brazil \\ E-mail:bm_conceicao@hotmail.com
}

\begin{abstract}
The COVID-19 pandemic is an unexpected historical event with an impact on all aspects of life - especially those of an occupational and mental nature. In a few months, it has altered daily life and social relations and, in addition to social distancing, isolation or quarantine, the world's population has to live with fear, insecurity and human and economic losses. Young people, particularly young women with a psychiatric history and no social support, are more vulnerable to the psycho-emotional consequences of the pandemic. The objective of this study was to observe the impact of COVID-19 on the mental health of students and their coping strategies. This was an observational study with a quantitative and cross-sectional method. The sample consisted of health students from a public university in the state of Paraíba, Brazil. Participants were recruited from the digital platforms in June 2020, a period of social isolation. The link to the Google forms questionnaire was made available on Instagram and WhatsApp. A total of 56 students, most of them women, answered the questionnaire. The most prevalent symptoms during social isolation were anxiety (76.8\%), concern (71.4\%), fear (62.5\%), insomnia (60.7\%) and sadness (55.4\%). Anxiety, depression, and hopelessness symptoms were more prevalent in younger female students with negative health perception. Complementary therapies and conversations with friends and family stand out as coping strategies. Mental health demands a convergence of efforts and institutional actions are needed to manage the psycho-emotional and neurobiological impact of COVID-19 in an integrated and integral way.
\end{abstract}


Keywords: Anxiety; Depression; Fear; Complementary therapies; Social isolation.

\begin{abstract}
Resumo
A pandemia da COVID-19 é um evento histórico impensado com impacto em todos os aspectos da vida - sobretudo o ocupacional e o mental. Em poucos meses, alterou o cotidiano e as relações sociais e, além do distanciamento social, isolamento ou quarentena, a população mundial convive com o medo, a insegurança e as perdas humanas e econômicas. Os jovens, principalmente do sexo feminino, com história psiquiátrica e sem suporte social são mais vulneráveis as consequências psicoemocionais da pandemia. O objetivo do estudo foi verificar o impacto da COVID19 na saúde mental dos estudantes e respectivas estratégias de enfrentamento. Trata-se de um estudo observacional com método quantitativo e transversal. A amostra foi constituída por estudantes da saúde de uma universidade pública do estado da Paraíba, Brasil. Em junho de 2020, período de isolamento social, recrutou-se os participantes nas plataformas digitais. O link do questionário disponível no Google forms foi disponibilizado no Instagram e WhatsApp. Atenderam à convocação 56 estudantes, a maioria do sexo feminino. Os sintomas mais prevalentes durante o isolamento social foram: ansiedade (76.8\%), preocupação (71.4\%), medo (62.5\%), insônia (60.7\%) e tristeza (55.4\%). Sintomas de ansiedade, depressão e desesperança foram mais prevalentes em estudantes mais jovens, do sexo feminino e com percepção negativa da saúde. Quanto às estratégias de enfrentamento destacam-se as terapias complementares e conversa com amigos e familiares. A saúde mental demanda convergência de esforços e aguarda as ações institucionais para gerenciar de forma integrada e integral o impacto psicoemocional e neurobiológico da COVID-19.
\end{abstract}

Palavras-chave: Ansiedade; Depressão; Medo; Terapias complementares; Isolamento social.

\begin{abstract}
Resumen
La pandemia de COVID-19 es un evento histórico irreflexivo con un impacto en todos los aspectos de la vida, especialmente ocupacional y mental. En pocos meses cambió la vida cotidiana y las relaciones sociales y, además del desapego social, el aislamiento o la cuarentena, la población mundial vive con miedo, inseguridad y pérdidas humanas y económicas. Los jóvenes, principalmente mujeres, con antecedentes psiquiátricos y sin apoyo social son más vulnerables a las consecuencias psicoemocionales de la pandemia. El objetivo del estudio fue verificar el impacto del COVID-19 en la salud mental de los estudiantes y sus estrategias de afrontamiento. Se trata de un estudio observacional con método cuantitativo y transversal. La muestra estuvo constituida por estudiantes de salud de una universidad pública del estado de Paraíba, Brasil. En junio de 2020, un período de aislamiento social, los participantes fueron reclutados en plataformas digitales. El enlace del cuestionario disponible en los formularios de Google se puso a disposición en Instagram y WhatsApp. 56 estudiantes asistieron a la convocatoria, la mayoría mujeres. Los síntomas más prevalentes durante el aislamiento social fueron: ansiedad (76.8\%), preocupación (71.4\%), miedo (62.5\%), insomnio (60.7\%) y tristeza (55.4\%). Los síntomas de ansiedad, depresión y desesperanza fueron más frecuentes en las estudiantes más jóvenes con percepciones negativas de la salud. En cuanto a estrategias de afrontamiento, destacan las terapias complementarias y la conversación con amigos y familiares. La salud mental demanda una convergencia de esfuerzos y espera acciones institucionales para manejar el impacto psicoemocional y neurobiológico de COVID19 de manera integrada e integral.
\end{abstract}

Palabras clave: Ansiedad; Depresión; Temor; Terapias complementarias; Aislamiento social.

\title{
1. Introduction
}

From Wuhan in China to the world, the Coronavirus disease 2019 (COVID-19) pandemic is an unexpected historical event with several consequences in the short, medium and long term. The number of confirmed cases and deaths is growing, impacting all aspects of life - especially those related to occupational and mental functioning. The pandemic has altered daily life and social relations and, in addition to social distancing, isolation or quarantine, the world's population has to deal with human and economic losses (Holmes et al., 2020). All this is associated with individual, sociodemographic, relational and community risk factors, and it constitutes a complex environment for emotional balance.

As such, unpleasant emotions, feelings and sensations may increase not only because of the increasing confirmation of cases and loss of life, but also due to the global financial decline (Rubin \& Wessely, 2020) and the lack of social support, especially in those who find themselves in conditions of personal and socioeconomic vulnerability. Fear and anxiety are common consequences of the pandemic and of mass social isolation and distancing. It is worth remembering that the inherent unexpected situations of disasters, wars and epidemics cause a devastating impact, both individually and collectively, and they can trigger diverse reactions, such as post-traumatic stress disorder (PTSD), anxiety disorder and depression. In addition, 
PTSD, anxiety, depression and hopelessness contribute to risk behaviors and the non-adherence to preventive or protective treatments and behaviors, which may sometimes lead to fatal outcomes.

Previous studies have pointed out risk factors for post-disaster mental illnesses, which include: female sex, younger age, race/color/ethnicity, little socioeconomic power, poor social support, bad relationships, previous trauma, and personal or family psychiatric history (Brewin, Andrews, \& Valentine, 2000; Goldmann \& Galea, 2014; Tortella-Feliu et al., 2019). Many of these factors are common to young students at Brazilian public universities. In this context, collecting data to identify the effects of the COVID-19 pandemic on the mental health and cognitive functions of the vulnerable population, on cured patients (Holmes et al., 2020) and on the general population, is a priority. The results have the potential to produce information on the psycho-emotional impact of COVID-19 on young students and to contribute to the design of support, prevention and follow-up strategies to avoid progression, complications and disabilities within this context.

The objective of the study was to observe the impact of the COVID-19 pandemic on the mental health of students at a public university during social isolation, in addition to the respective services and forms of support used.

\section{Methodology}

This is an observational study with a quantitative and cross-sectional methodology. The health students of a public university in the state of Paraíba, Brazil, are its target population. The non-probabilistic sample was made up of students of both sexes, over 18 years old (Pereira, Shitsuka, Parreira, \& Shitsuka, 2018; Vieira \& Hossne, 2020). The project was approved by the Research Ethics Committee of the CCS/UFPB (registration no. 4.046.363; CAAE 92087118.6.0000.5188). All volunteers were informed about the objectives of the research and the anonymity of the information in the questionnaire, and they agreed through the Free and Informed Consent Term when they chose to participate.

The recruitment of participants took place in June 2020. The form link was made available in the Instagram biography of the @ neuroconexoesufpb project and in the WhatsApp of the student groups. The data collection tool was developed on Google forms with questions related to socio-demographics, health perception and history, and care strategies used before and during social isolation. Issues related to self-perception and the self-reporting of symptoms that alter the emotional balance and have associations with states of anxiety, depression and hopelessness were used based on the Beck inventories, Beck Anxiety Inventory-BAI, Beck Depression Inventory - BDI and Beck Hopelessness Scale - BHS (Cunha, 2017).

\subsection{Statistical Analysis}

The statistical analysis consisted of: 1) description of the prevalence of socio-demographic and health data;2) analysis of the relationship between the variables with the chi-square test or Fisher's exact test; 3) the Student t or ANOVA test was used in the comparison of the age means. The analyses were performed in the Statistical Package for the Social Sciences (SPSS) 25 at the 5\% significance level.

\section{Results and Discussion}

The questionnaire was answered by 56 students of both sexes, with a mean age of $21.5 \pm 3.2$ years, enrolled in the 1st to the 9th period of nine courses in the field of health care. There was a predominance of the northeast region of Brazil regarding the place of birth, mainly the states of Paraíba and Pernambuco. The participants were mostly women, single and had a preference for Christian religions. See Table 1 for more information on the characteristics of the participants. 
Table 1 - Characteristics of the students participating in the research. João Pessoa-PB, 2020.

\begin{tabular}{|c|c|c|c|}
\hline VARIABLES & CATEGORIES & $\mathbf{N}$ & $\%$ \\
\hline \multirow{2}{*}{ Sex } & Female & 46 & 82.1 \\
\hline & Male & 10 & 17.9 \\
\hline \multirow{4}{*}{ Marital Status } & Single & 45 & 80.4 \\
\hline & Stable union & 06 & 10.7 \\
\hline & Married & 01 & 1.8 \\
\hline & Divorced & 01 & 1.8 \\
\hline \multirow{2}{*}{$\begin{array}{l}\text { Place of Birth } \\
\text { Region of Brazil }\end{array}$} & Northeast & 50 & 89.3 \\
\hline & Southeast & 6 & 10.7 \\
\hline \multirow{6}{*}{$\begin{array}{l}\text { Place of Birth } \\
\text { State }\end{array}$} & Paraíba & 38 & 67.9 \\
\hline & Pernambuco & 10 & 17.9 \\
\hline & Rio de Janeiro & 3 & 5.4 \\
\hline & São Paulo & 3 & 5.4 \\
\hline & Rio Grande do Norte & 1 & 1.8 \\
\hline & Bahia & 1 & 1.8 \\
\hline \multirow{8}{*}{ Religious Preference } & Catholicism & 30 & 53.6 \\
\hline & Spiritism & 9 & 16.1 \\
\hline & No religious preference & 8 & 14.3 \\
\hline & Protestantism/Evangelical & 6 & 10.7 \\
\hline & Umbanda & 3 & 5.4 \\
\hline & Buddhism & 2 & 3.6 \\
\hline & Candomblé & 1 & 1.8 \\
\hline & Hinduism & 1 & 1.8 \\
\hline \multirow{9}{*}{ Courses } & Occupational Therapy & 21 & 37.5 \\
\hline & Speech Therapy & 11 & 19.6 \\
\hline & Physical Therapy & 5 & 8.9 \\
\hline & Pharmacy & 5 & 8.9 \\
\hline & Medicine & 5 & 8.9 \\
\hline & Biomedicine & 4 & 7.1 \\
\hline & Nursing & 2 & 3.6 \\
\hline & Dentistry & 2 & 3.6 \\
\hline & Nutrition & 1 & 1.8 \\
\hline \multirow{2}{*}{ Alcohol use } & Yes & 32 & 57.1 \\
\hline & No & 24 & 42.9 \\
\hline \multirow{2}{*}{ Smoking } & Yes & 3 & 5.4 \\
\hline & No & 53 & 94.6 \\
\hline \multirow{2}{*}{ Health Insurance } & Yes & 16 & 28.6 \\
\hline & No & 40 & 71.4 \\
\hline
\end{tabular}

Source: Research data.

\subsection{Self-perception of Health and Prior Pathological History}

In general, the 56 participants, aged 18 to 39 years and with a mean weight of $65.89 \pm 14.80 \mathrm{Kg}$, had a positive selfperception of health, classifying it as good (33.9\%), very good (26.8\%) and excellent (1.8\%). As can be seen, 55.6\% of the students feel well, mainly those with a higher mean age (22.2 \pm 3.9 , Table 2$)$. Some students, however, considered their own health to be regular $(28.6 \%)$ or bad $(8.9 \%)$, which indicates a negative self-perception of health, which was confirmed when participants declared they felt sick $(28.6 \%)$, perceived some symptom they considered to have a pathological significance 
$(57.1 \%)$, or used some mental health service during the pandemic/social isolation (37.5\%). Students who feel sick are significantly younger $(\mathrm{p}=0.03)$ and have a mean age of $20.3 \pm 1.5$ years. See Table 2 for more details.

Table 2 - Prevalence of health-related information, with respective mean ages and standard deviations. João Pessoa-PB, 2020.

\begin{tabular}{|c|c|c|c|c|}
\hline \multicolumn{2}{|l|}{ VARIABLES } & \multirow{2}{*}{$\begin{array}{l}\mathbf{N} \\
31\end{array}$} & \multirow{2}{*}{$\begin{array}{c}\% \\
55.4\end{array}$} & \multirow{2}{*}{$\begin{array}{c}\text { MEAN AGE } \\
p \\
003\end{array}$} \\
\hline \multirow{2}{*}{ I feel well } & Yes & & & \\
\hline & No & 25 & 44.6 & $\mathbf{0 . 0 3}$ \\
\hline \multirow{2}{*}{ Feels sick } & Yes & 16 & 28.6 & \multirow{2}{*}{$\mathbf{0 . 0 3}$} \\
\hline & No & 40 & 71.4 & \\
\hline \multirow{2}{*}{ Do you engage in any physical activity? } & Yes & 26 & 46.4 & \multirow{2}{*}{0.53} \\
\hline & No & 30 & 53.6 & \\
\hline \multirow{2}{*}{ Symptom that you consider to have a pathological significance } & Yes & 32 & 57.1 & \multirow{2}{*}{0.09} \\
\hline & No & 24 & 42.9 & \\
\hline \multirow{2}{*}{ Feels pain every day } & Yes & 09 & 16.1 & \multirow{2}{*}{0.68} \\
\hline & No & 47 & 83.9 & \\
\hline \multirow{2}{*}{ Pain several times a week } & Yes & 26 & 46.4 & \multirow{2}{*}{0.08} \\
\hline & No & 30 & 53.6 & \\
\hline \multirow{2}{*}{ Trouble sleeping due to pain } & Yes & 11 & 19.6 & \multirow{2}{*}{0.49} \\
\hline & No & 45 & 80.4 & \\
\hline \multirow{2}{*}{ In the last seven days, has the pain made you feel sad or depressed? } & Yes & 18 & 32.1 & \multirow{2}{*}{0.90} \\
\hline & No & 38 & 67.9 & \\
\hline \multirow{2}{*}{ Have you engaged in any complementary/alternative therapy? } & Yes & 43 & 76.8 & \multirow{2}{*}{0.45} \\
\hline & No & 13 & 23.2 & \\
\hline \multirow{2}{*}{ Have you had psychological treatment? } & Yes & 30 & 53.6 & \multirow{2}{*}{0.46} \\
\hline & No & 26 & 46.4 & \\
\hline \multirow{2}{*}{ Have you had psychiatric treatment? } & Yes & 13 & 23.2 & \multirow{2}{*}{0.09} \\
\hline & No & 43 & 76.8 & \\
\hline \multirow{2}{*}{ Have you had neurological treatment? } & Yes & 08 & 14.3 & \multirow{2}{*}{0.32} \\
\hline & No & 48 & 85.7 & \\
\hline \multirow{2}{*}{ Did you use any mental health service during the pandemic? } & Yes & 21 & 37.5 & \multirow{2}{*}{0.84} \\
\hline & No & 35 & 62.5 & \\
\hline \multirow{2}{*}{ Are you currently on any medication? } & Yes & 23 & 41.1 & \multirow{2}{*}{0.39} \\
\hline & No & 33 & 58.9 & \\
\hline
\end{tabular}

$p<0.05$ considered significant. Source: Research data.

Note in Tables 1 and 2 that most students are female, have no health insurance, complain of pain and have already undergone some psychological (53.6\%), psychiatric (23.2\%) or neurological (14.3\%) treatment. These variables are important risk factors for post-pandemic mental health and point to the need for the social support and monitoring of this population.

Regarding the reports of pathologies with previous medical or dental diagnosis, the most common reports were: allergic rhinitis (23.2\%), migraine (19.6\%), clinical depression (19.6\%), anxiety disorder (19.6\%), sinusitis (17.9\%) and headaches (12.5\%) (Figure 1). There were no diagnostic reports of COVID-19 among the respondents.

The analysis of the presence and intensity of certain diseases, especially when they are self-reported, is an important tool to determine their effects on the individual's mental and physical health. Before the COVID-19 pandemic, depression affected $5.8 \%$ of the population in Brazil, while anxiety-related disorders affected 9.3\%. These can lead to suicide, which in 2015 caused 788,000 deaths worldwide, 78\% of them in low-income countries (WHO, 2017). 
The depressive and anxiety symptoms in this study are of concern, especially when the data of the population and other institutions from before and during the pandemic are compared (Brandtner \& Bardagi, 2009; Stella \& Sommerhalder, 2000; Stopa et al., 2015; Tang et al., 2020; Wang, Wen, Dong, Liu, \& Cui, 2020). Figure 1 shows a summary of the pathological history, especially regarding psychopathological and neurological issues, and the psycho-emotional complaints of the students during the pandemic.

Figure 1 - Summary of the prevalence of a pathological history, complaints in the last month and psycho-emotional symptoms in the last week $(\mathrm{n}=56)$. João Pessoa, 2020.

\begin{tabular}{|c|c|c|}
\hline & Social Isol & lation \\
\hline $\begin{array}{l}\text { Pathological History } \\
\text { - Anxiety: } 19,6 \% \\
\text { - Depression: } 19,6 \% \\
\text { - Migraine: } 19,6 \% \\
\text { - Headaches: } 12,5 \% \\
\text { - Disease anxiety: } 5,4 \% \\
\text { - Bulimia: } 3,6 \% \\
\text { - Bipolar disorders: } 1,8 \% \\
\text { - Obsessive-compulsive disorder: } \\
1,8 \%\end{array}$ & $\begin{array}{l}\quad \text { Last Month } \\
\text { - Anxiety: } 76,8 \% \\
\text { - Concern: } 71,4 \% \\
\text { - Fear: } 62,5 \% \\
\text { - Insomnia: } 60,7 \% \\
\text { - Sadness: } 55,4 \% \\
\text { - Difficulties concentrating: } 55,4 \% \\
\text { - Headaches: } 51,8 \% \\
\text { - Nightmares: } 46,4 \% \\
\text { - Sensation of insecurity: } 46,4 \% \\
\text { - Migraine: } 35,7 \% \\
\text { - Tinnitus: } 25,0 \%\end{array}$ & $\begin{array}{l}\text { Lost Week } \\
\text { - Fear that the worst will happen: } 69,6 \% \\
\text { - Nervous: } 67,9 \% \\
\text { - Scared: } 67,9 \% \\
\text { - Unable to relax: } 58,9 \% \\
\text { - Sadness: } 60,7 \% \\
\text { - Disheartened regarding the future: } \\
66,1 \% \\
\text { - The future seems vague and uncertain } \\
\text { to me: } 57,1 \% \\
\text { - Suicidal Ideation: } 10,7 \%\end{array}$ \\
\hline
\end{tabular}

Source: Authors.

A study conducted with students in Guangzhou, China, found a prevalence of $7.7 \%$ for anxiety and depression during the initial peak of COVID-19 in China in the months of January and February (Wang, Wen, Dong, Liu, \& Cui, 2020). Another study with students at six Chinese universities during quarantine found a prevalence of $9.0 \%$ for depressive symptoms in the sample and also found that students in their final year of graduation had more depressive and post-traumatic stress disorder symptoms. In addition, fear was the most significant risk factor for psychological distress (Tang et al., 2020). In the psychopathological history of the sample of this study, the prevalence of depression was $19.6 \%$, with the same percentage being found for anxiety, which is higher than the Chinese data during the pandemic. In addition, the most prevalent complaint is found in the headache group (migraines and headaches). Added to the fear and psycho-emotional data, this points to a prevalence of psychological distress and a consequent increase in the demand for psychiatry, psychology and neurology services during and after the pandemic.

The WHO has stated that pre-existing mental and neurological disorders increase the risk of long-term complications and also of death (WHO, 2020). This reveals the need to invest in observational research to monitor the psycho-emotional, social and neuropsychiatric impact of the pandemic on vulnerable populations, such as people with a history of mental disorders or neurological diseases with psychological and psychiatric repercussions. It is about preventing and maintaining the 
well-being, quality of life and life expectancy of these populations, because cognitive alterations, the worsening of pre-existing disorders, distortions in the risk perception and the consequent negligence of individual or collective protection measures can result in personal and family losses that may be irreversible (Talevi et al., 2020).

\subsection{Health: Complaints During the Pandemic and Social Isolation}

Most participants mentioned the following complaints when questioned about the last month, the pandemic and social isolation period: anxiety (76.8\%), concern (71.4\%), fear (62.5\%), insomnia (60.7\%), sadness (55.4\%), difficulties concentrating (55.4\%) and headaches (51.8\%). In addition, nightmares (46.4\%), a sensation of insecurity (46.4\%), migraines (35.7\%), tinnitus (25.0\%) and tingling (16.1\%) were also registered (Figure 1). The data shows the psycho-emotional impact of the pandemic and the related social isolation among students in the field of health care. On can see here that in addition to the already mentioned diagnosed cases of clinical depression (19.6\%) and anxiety disorder (19.6\%), a prevalence can be observed of self-reported anxiety, concern and fear, symptoms that should be expected in a pandemic period that changed the daily lives of all countries affected by COVID-19 (Gagliato, 2020; Ornell, Schuch, Sordi, \& Kessler, 2020). These data again explain the reported use of mental health services during the pandemic, which reached 37.5 among the participants of the sample.

In the next sections, the self-reported data are described regarding the signs or symptoms of anxiety, depression, and hopelessness related to the last week, a period of social isolation.

\subsubsection{Anxiety: Self-reported Anxiety Symptoms in the Period of Social Isolation}

Most participants reported anxiety (76.8\%); others mentioned having received a medical diagnosis of anxiety disorder $(19.6 \%)$, in addition to illness anxiety disorder (5.4\%), in their pathological history (Figure 1). When considering the last week, the students mentioned the anxiety symptoms shown in Table 3. As can be seen, "fear of the worst" was greater among female participants and among those with negative self-perception of health. Nevertheless, there was no statistically significant difference between the anxiety symptoms and the categorical variables analyzed, as can be seen in Table 4.

Table 3 - Self-reported signs or symptoms of anxiety in the last week, period of social isolation.

\begin{tabular}{|c|c|}
\hline SIGNS AND SYMPTOMS OF ANXIETY & $\begin{array}{c}\text { TOTAL } \\
\mathbf{N}(\%) \\
\end{array}$ \\
\hline Fear that the worst will happen & $39(69.6)$ \\
\hline Nervous & $38(67.9)$ \\
\hline Scared & $38(67.9)$ \\
\hline Unable to relax & $33(58.9)$ \\
\hline Heart palpitation/acceleration & $28(50.0)$ \\
\hline Fear of losing control & $24(42.9)$ \\
\hline Difficulty breathing & $21(37.5)$ \\
\hline Indigestion or discomfort in the abdomen & $20(35.7)$ \\
\hline Fear of dying & $19(33.9)$ \\
\hline Hot sensation & $18(32.1)$ \\
\hline Suffocating sensation & $17(30.4)$ \\
\hline Stunned or dizzy & $17(30.4)$ \\
\hline Numbness or tingling & $12(21.4)$ \\
\hline Shaking of the hands & $15(26.8)$ \\
\hline Trembling & $13(23.2)$ \\
\hline Terrified & $9(16.1)$ \\
\hline Sweat not due to heat & $9(16.1)$ \\
\hline Shaking of the legs & $8(14.3)$ \\
\hline No balance & $8(14.3)$ \\
\hline Feeling faint & $7(12.5)$ \\
\hline
\end{tabular}


Table 4 - Analysis of anxiety symptoms of students in the period of social isolation $(\mathrm{N}=54)$.

\begin{tabular}{|c|c|c|c|c|c|c|}
\hline \multirow{2}{*}{$\begin{array}{l}\text { VARIABLES AND } \\
\text { CATEGORIES }\end{array}$} & \multicolumn{3}{|c|}{$\begin{array}{c}\text { FEAR THAT THE WORST } \\
\text { WILL HAPPEN }\end{array}$} & \multicolumn{3}{|c|}{ UNABLE TO RELAX } \\
\hline & $\begin{array}{c}\text { No } \\
\mathrm{N}(\%)\end{array}$ & $\begin{array}{c}\text { Yes } \\
\mathrm{N}(\%)\end{array}$ & $p$ & $\begin{array}{c}\text { No } \\
\mathrm{N}(\%)\end{array}$ & $\begin{array}{c}\text { Yes } \\
\mathrm{N}(\%)\end{array}$ & $p$ \\
\hline \multicolumn{7}{|c|}{ Self-declared Race/Ethnicity/Color* } \\
\hline White & $11(36.7)$ & $19(63.3)$ & \multirow{3}{*}{0.43} & $10(33.3)$ & $20(66.7)$ & \multirow{3}{*}{0.46} \\
\hline Mixed (Pardo) & $4(22.2)$ & $14(77.8)$ & & $9(50.0)$ & $9(50.0)$ & \\
\hline Black & $1(16.7)$ & $5(83.3)$ & & $3(50.0)$ & $3(50.0)$ & \\
\hline \multicolumn{7}{|l|}{ Sex } \\
\hline Female* & $11(25.0)$ & $33(75.0)$ & \multirow{2}{*}{0.14} & $17(38.6)$ & $27(61.4)$ & \multirow{2}{*}{0.72} \\
\hline Male & $5(50.0)$ & $5(50.0)$ & & $5(50.0)$ & $5(50.0)$ & \\
\hline \multicolumn{7}{|l|}{ Relationship status } \\
\hline Not in a relationship & $15(31.4)$ & $29(65.9)$ & \multirow{2}{*}{0.24} & $18(40.9)$ & $26(59.1)$ & \multirow{2}{*}{1.00} \\
\hline In a relationship & $1(10.0)$ & $9(90.0)$ & & $4(40.0)$ & $6(60.0)$ & \\
\hline \multicolumn{7}{|l|}{ Religious Preference } \\
\hline Has no religious preference & $2(25.0)$ & $6(75.0)$ & \multirow{2}{*}{1.00} & $4(50.0)$ & $4(50.0)$ & \multirow{2}{*}{0.7} \\
\hline Has a religious preference & $14(30.4)$ & $32(69.6)$ & & $18(39.1)$ & $28(60.9)$ & \\
\hline \multicolumn{7}{|l|}{ Self-perception of health } \\
\hline Bad & $0(0)$ & $5(100)$ & \multirow{4}{*}{0.39} & $0(0)$ & $5(100)$ & \multirow{4}{*}{0.19} \\
\hline Regular & $4(26.7)$ & $11(73.3)$ & & $8(53.3)$ & $7(46.7)$ & \\
\hline Good & $6(31.6)$ & $13(68.4)$ & & $7(36.8)$ & $12(63.2)$ & \\
\hline Very good & $6(40.0)$ & $9(60.0)$ & & $7(46.7)$ & $8(53.3)$ & \\
\hline
\end{tabular}

*Two participants were excluded due to lack of response of the independent variable color/ethnicity/race that best describes their ancestry.

Source: Research data.

Table 3 shows the high prevalence of fear (fear of the worst, fear of losing control, and fear of dying) among students, perhaps due to the new virus with uncertain origins and treatment, the lack of social support, and personal vulnerabilities. Fear, anxiety, lack of social support, misinformation and other risk factors may be associated with the emerging coronaphobia (Naguy, Moodliar-Rensburg \& Alamiri, 2020).

Table 4 shows that in addition to the risk factors already described in the literature, the variables relationship status and health self-perception appear to be important for emotional balance, and they are potential mental health risk factors.

The study conducted with university students of the Changzhi Medical School in China suggested different levels of anxiety in students, with variations between the mild $(21.3 \%)$, moderate $(2.7 \%)$ and severe $(0.9 \%)$ anxiety levels. The study suggested the following protective factors against anxiety: living in urban areas; stability of family income; and, finally, living with parents. Meanwhile, having relatives or acquaintances infected by COVID-19 was a risk factor to increase the anxiety of university students. The authors suggest monitoring the mental health of university students during epidemics (Cao et al., 2020).

\subsubsection{Depression}

As for the depressive symptoms, there was a high prevalence of self-criticism (85.7\%). When comparing the symptoms with the mean age of the respondents, the youngest students, with a mean age of 20 years, generally reported more depressive symptoms (Table 5). Among the participants, $10.7 \%$ declared having suicidal thoughts. In addition to the several symptoms related to depression, it is noteworthy that $19.6 \%$ of these students have a history of clinical depression and $23.2 \%$ have already undergone psychiatric treatment. 
Table 5 - Prevalence of depressive symptoms and respective means and standard deviations of the respondents' age. João Pessoa, Brazil, 2020.

\begin{tabular}{lccc}
\hline \multicolumn{1}{c}{ SIGNS AND SYMPTOMS OF DEPRESSION } & $\begin{array}{c}\text { TOTAL } \\
\text { N (\%) }\end{array}$ & $\begin{array}{c}\text { MEAN } \\
\text { AGE }\end{array}$ & $p$ \\
\hline I'm critical of myself regarding my weaknesses or mistakes & $48(85.7)$ & $21.1 \pm 2.2$ & 0.80 \\
\hline I get upset or irritated more easily than I used to & $38(67.9)$ & $20.7 \pm 1.7$ & 0.09 \\
\hline I get tired more easily than I used to & $\mathbf{3 7}(\mathbf{6 6 . 1})$ & $\mathbf{2 0 . 8} \pm \mathbf{2 . 3}$ & $\mathbf{0 . 0 4}$ \\
\hline Disheartened regarding the future & $37(66.1)$ & $21.3 \pm 2.3$ & 0.90 \\
\hline I don't sleep as well as I used to & $35(62.5)$ & $21.1 \pm 1.7$ & 0.47 \\
\hline Sadness & $34(60.7)$ & $20.9 \pm 1.7$ & 0.34 \\
\hline I am less interested in other people & $31(55.4)$ & $20.8 \pm 1.7$ & 0.11 \\
\hline I've gained more than 2.5Kg & $29(51.8)$ & $21.7 \pm 4.2$ & 0.34 \\
\hline I postpone decisions more than I used to & $29(51.8)$ & $21.1 \pm 2.5$ & 0.21 \\
\hline I think I look ugly & $\mathbf{2 7 ( 4 8 . 2 )}$ & $\mathbf{2 0 . 7 \pm 1 . 6}$ & $\mathbf{0 . 0 3}$ \\
\hline I am disappointed in myself & $26(46.4)$ & $20.7 \pm 1.5$ & 0.20 \\
\hline I don't feel pleasure in things as before & $\mathbf{2 5 ( 4 4 . 6 )}$ & $\mathbf{2 0 . 6} \pm \mathbf{1 . 8}$ & $\mathbf{0 . 0 4}$ \\
\hline I'm worried about looking old or unattractive & $24(42.9)$ & $21.0 \pm 1.6$ & 0.40 \\
\hline I feel guilty most of the time & $19(33.9)$ & $21.2 \pm 2.7$ & 0.63 \\
\hline I cry more now & $\mathbf{1 8 ( 3 2 . 1 )}$ & $\mathbf{2 0 . 4} \pm \mathbf{1 . 5}$ & $\mathbf{0 . 0 3}$ \\
\hline I think I could be punished & $14(25.0)$ & $20.6 \pm 1.2$ & 0.69 \\
\hline
\end{tabular}

$p<0.05$ considered significant. Source: Research data.

Note in Table 5 that the younger students reported more depressive symptoms. Of these, the items related to fatigability, self-image, dissatisfaction and crying were statistically significant. Note also the prevalence of sleep disorders and weight changes.

Table 6 - Depressive symptoms among participants, according to independent qualitative variables.

\begin{tabular}{|c|c|c|c|c|c|c|}
\hline \multirow{2}{*}{$\begin{array}{c}\text { VARIABLES } \\
\text { AND } \\
\text { CATEGORIES }\end{array}$} & \multicolumn{3}{|c|}{$\begin{array}{c}\text { UPSET OR IRRITATED MORE } \\
\text { EASILY THAN USUAL } \\
\end{array}$} & \multicolumn{3}{|c|}{$\begin{array}{c}\text { DISHEARTENED } \\
\text { REGARDING THE FUTURE }\end{array}$} \\
\hline & $\begin{array}{c}\text { No } \\
\mathrm{N}(\%) \\
\end{array}$ & $\begin{array}{c}\text { Yes } \\
\mathrm{N}(\%) \\
\end{array}$ & $p$ & $\begin{array}{c}\text { No } \\
\mathrm{N}(\%) \\
\end{array}$ & $\begin{array}{c}\text { Yes } \\
\mathrm{N}(\%) \\
\end{array}$ & $p$ \\
\hline \multicolumn{7}{|c|}{ Self-declared Race/Ethnicity/Color } \\
\hline White & $7(23.3)$ & $23(76.7)$ & \multirow{3}{*}{0.31} & $6(20.0)$ & $24(80.0)$ & \multirow{3}{*}{0.06} \\
\hline Mixed (Pardo) & $7(38.9)$ & $11(61.1)$ & & $9(50.0)$ & $9(50.0)$ & \\
\hline Black & $3(50.0)$ & $3(50.0)$ & & $3(50.0)$ & $3(50.0)$ & \\
\hline \multicolumn{7}{|l|}{ Sex } \\
\hline Female & $11(25.0)$ & $33(75.0)$ & \multirow{2}{*}{0.56} & $14(31.8)$ & $30(68.2)$ & \multirow{2}{*}{0.71} \\
\hline Male & $6(60.0)$ & $4(40.0)$ & & $4(40.0)$ & $6(60.0)$ & \\
\hline \multicolumn{7}{|l|}{ Relationship status } \\
\hline Not in a relationship & $12(27.3)$ & $32(72.7)$ & \multirow{2}{*}{0.25} & $13(29.5)$ & $31(70.5)$ & \multirow{2}{*}{0.27} \\
\hline In a relationship & $5(50.0)$ & $5(50.0)$ & & $5(50.0)$ & $5(50.0)$ & \\
\hline \multicolumn{7}{|l|}{ Religious Preference } \\
\hline Has no preference & $3(37.5)$ & $5(62.5)$ & \multirow{2}{*}{0.69} & $4(50.0)$ & $4(50.0)$ & \multirow{2}{*}{0.41} \\
\hline Has a preference & $14(30.4)$ & $32(69.6)$ & & $14(30.4)$ & $32(69.6)$ & \\
\hline \multicolumn{7}{|c|}{ Self-perception of health } \\
\hline Bad & $0(0)$ & $5(100)$ & \multirow{4}{*}{0.35} & $0(0)$ & $5(100)$ & \multirow{4}{*}{0.25} \\
\hline Regular & $4(26.7)$ & $11(73.3)$ & & $7(46.7)$ & $8(53.3)$ & \\
\hline Good & $7(36.8)$ & $12(63.2)$ & & $7(36.8)$ & $12(63.2)$ & \\
\hline Very good & $6(40.0)$ & $9(60)$ & & $4(26.7)$ & $11(73.3)$ & \\
\hline
\end{tabular}

*Two participants were excluded due to lack of response of the independent variable color/ethnicity/race that best describes their ancestry.

Source: Research data. 
Table 6 shows that irritation and pessimism (discouragement about the future) were higher among female students, with no relationship and with a negative health self-perception. Many vague complaints, sensations and even pains can hide depression. In addition, the experience of sensations, emotions and feelings related to psychological distress are not taken seriously enough, thus making it difficult to seek help and delaying the diagnosis and proper treatment of mental disorders. In the depressive process, it is common to experience feelings of prolonged sadness, loss of interest, weight and sleep changes, irritation, tiredness and feelings of uselessness and guilt (WHO, 2000). All of these have prevalence among the health students evaluated in this study.

\subsubsection{Hopelessness}

Most students $(58.9 \%)$ have great faith in the future, but for many at that moment, the future seemed vague and uncertain (57.1\%). Positive expectations regarding the future prevailed among students with higher mean age (Table 7). Uncertainties regarding the future were most mentioned among female students with poor self-perception of health and suicidal thoughts $(\mathrm{N}=6 ; 100 \%)$.

Table 7 - Prevalence of expectations regarding the future according to mean age and gender. João Pessoa-PB, 2020.

\begin{tabular}{lcccc}
\hline \multicolumn{1}{c}{ STATEMENTS } & YES & \multicolumn{1}{c}{ MEAN AGE } & SEX \\
\cline { 2 - 5 } & N (\%) & Mean \pm S.D. & $p$ & $p$ \\
\hline In the future I hope to succeed in what interests me most & $51(91.1)$ & $21.5 \pm 3.3^{*}$ & 0.75 & 0.57 \\
\hline I can expect more good times than bad & $37(66.1)$ & $21.7 \pm 3.7^{*}$ & 0.63 & 0.47 \\
\hline I have great faith in the future & $33(58.9)$ & $21.4 \pm 2.4$ & 0.62 & 0.72 \\
\hline The future seems vague and uncertain to me & $32(57.1)$ & $21.5 \pm 2.3$ & 0.25 & 0.31 \\
\hline I have enough time to accomplish the things I want & $\mathbf{2 6 ( 4 6 . 4 )}$ & $\mathbf{2 2 . 4 \pm 4 . 2 *}$ & $\mathbf{0 . 0 4}$ & 1.00 \\
\hline I think about the future with hope and enthusiasm & $24(42.9)$ & $21.7 \pm 3.9^{*}$ & 0.77 & 0.30 \\
\hline
\end{tabular}

S.D. = Standard Deviation; *Higher mean age. Source: Research data.

The data in Tables 7 and 8 shows that age, health self-perception and suicidal thoughts are important variables in the cognitive conception of hopelessness. 
Table 8 - Cognition regarding the future among students in the field of health care. João Pessoa-PB, 2020.

\begin{tabular}{|c|c|c|c|c|c|c|}
\hline \multirow{2}{*}{$\begin{array}{l}\text { VARIABLES AND } \\
\text { CATEGORIES }\end{array}$} & \multicolumn{3}{|c|}{$\begin{array}{c}\text { THE FUTURE SEEMS VAGUE } \\
\text { AND UNCERTAIN TO ME }\end{array}$} & \multicolumn{3}{|c|}{$\begin{array}{c}\text { I HAVE GREAT FAITH } \\
\text { IN THE FUTURE }\end{array}$} \\
\hline & $\begin{array}{c}\text { No } \\
\mathrm{N}(\%) \\
\end{array}$ & $\begin{array}{c}\text { Yes } \\
\mathrm{N}(\%) \\
\end{array}$ & $p$ & $\begin{array}{c}\text { No } \\
\mathrm{N}(\%) \\
\end{array}$ & $\begin{array}{c}\text { Yes } \\
\mathrm{N}(\%) \\
\end{array}$ & $p$ \\
\hline \multicolumn{7}{|c|}{ Self-declared Race/Ethnicity/Color } \\
\hline White & $11(36.7)$ & $19(63.3)$ & \multirow{3}{*}{0.42} & $14(46.7)$ & $16(53.3)$ & \multirow{3}{*}{0.10} \\
\hline Mixed (Pardo) & $10(55.6)$ & $8(44.4)$ & & $7(38.9)$ & $11(61.1)$ & \\
\hline Black & $3(50.0)$ & $3(50.0)$ & & $0(0)$ & $6(100)$ & \\
\hline \multicolumn{7}{|l|}{ Sex } \\
\hline Female & $18(40.9)$ & $26(59.1)$ & \multirow{2}{*}{0.31} & $18(40.9)$ & $26(59.1)$ & \multirow{2}{*}{0.72} \\
\hline Male & $6(60.0)$ & $4(40.0)$ & & $3(30.0)$ & $7(70.0)$ & \\
\hline \multicolumn{7}{|l|}{ Relationship status } \\
\hline Not in a relationship & $19(43.2)$ & $25(56.8)$ & \multirow{2}{*}{0.73} & $18(40.9)$ & $26(59.1)$ & \multirow{2}{*}{0.72} \\
\hline In a relationship & $5(50.0)$ & $5(50.0)$ & & $3(30.0)$ & $7(70.0)$ & \\
\hline \multicolumn{7}{|l|}{ Religious Preference } \\
\hline Has no religious preference & $4(50.0)$ & $4(50.0)$ & \multirow{2}{*}{1.00} & $4(50.0)$ & $4(50.0)$ & \multirow{2}{*}{0.69} \\
\hline Has a religious preference & $20(43.5)$ & $26(56.5)$ & & $17(37.0)$ & $29(63.0)$ & \\
\hline \multicolumn{7}{|l|}{ Self-perception of health } \\
\hline Bad & $0(0)$ & $5(100)$ & \multirow{4}{*}{0.13} & $4(80.0)$ & $1(20.0)$ & \multirow{4}{*}{0.15} \\
\hline Regular & $9(60.0)$ & $6(40.0)$ & & $7(46.7)$ & $8(53.3)$ & \\
\hline Good & $8(42.1)$ & $11(57.9)$ & & $6(31.6)$ & $13(68.4)$ & \\
\hline Very good & $7(46.7)$ & $8(53.3)$ & & $4(26.7)$ & $11(73.3)$ & \\
\hline \multicolumn{7}{|l|}{ Suicidal Ideas } \\
\hline Yes & $0(0)$ & $6(100)$ & \multirow{2}{*}{$0.03 *$} & $5(83.3)$ & $1(16.7)$ & \multirow{2}{*}{0.07} \\
\hline No & $24(48)$ & $26(52)$ & & $18(36)$ & $32(64)$ & \\
\hline
\end{tabular}

*At least one cell has expected size $<5$. Chi-square may not be a valid test. Source: Research data.

Hopelessness is a cognitive dimension that results in a loss of motivation and expectations about the future and it is associated with depression and suicidal ideation, with the WHO considering it as a risk factor for suicide (Cunha, 2017; WHO, 2014). In this work, self-perception of health seems important in the cognition of hopelessness and suicidal ideation.

\subsubsection{Suicidal Ideation}

Suicide is a complex and multidimensional public health problem and usually involves the connection of several risk factors (WHO, 2014). Depression associated with fear, hopelessness, and lack of support can lead to self-destructive thoughts and culminate in death resulting from suicidal thoughts. Six participants in the sample (10.7\%), with a mean age of $20.7 \pm 1.6$ years, reported having suicidal thoughts. Most in this group are women $(n=5 ; 83.3 \%)$, self-declared whites $(n=4 ; 66.7 \%)$, and have already undergone psychological $(n=5 ; 83.3 \%)$ or psychiatric $(n=2 ; 33.3 \%)$ treatment. All $(n=6 ; 100 \%)$ reported feeling sadness and thinking that they have failed more than an ordinary person. Negative self-perception of health and the use of medication had significant statistical relation with suicidal thoughts $(\mathrm{p}<0.01)($ Table 9$)$. 
Table 9 - Suicidal thoughts among participants according to sociodemographic data and health history $(\mathrm{N}=54)$.

\begin{tabular}{|c|c|c|c|}
\hline \multirow[b]{2}{*}{ VARIABLES } & \multicolumn{2}{|c|}{ SUICIDAL THOUGHTS } & \multirow[b]{2}{*}{$p$} \\
\hline & $\begin{array}{c}\text { NO } \\
\text { N (\%) }\end{array}$ & $\begin{array}{c}\text { YES } \\
\mathbf{N}(\%)\end{array}$ & \\
\hline \multicolumn{4}{|l|}{ Self-declared Race/Ethnicity/Color } \\
\hline White & $26(86.7)$ & $4(13.3)$ & \multirow{3}{*}{0.63} \\
\hline Mixed (Pardo) & $16(88.9)$ & $2(11.1)$ & \\
\hline Black & $6(100)$ & $0(0)$ & \\
\hline \multicolumn{4}{|l|}{ Sex } \\
\hline Female & $39(88.6)$ & $5(11.4)$ & \multirow{2}{*}{1.00} \\
\hline Male & $9(90.0)$ & $1(10.0)$ & \\
\hline \multicolumn{4}{|l|}{ Relationship status } \\
\hline No relationship (single) & $39(88.6)$ & $5(11.4)$ & \multirow{2}{*}{1.00} \\
\hline In a relationship (married, dating, engaged, stable union) & $9(90.0)$ & $1(10.0)$ & \\
\hline \multicolumn{4}{|l|}{ Religious status } \\
\hline Has no religious preference & $6(75.0)$ & $2(25.0)$ & \multirow{2}{*}{0.21} \\
\hline Has a religious preference & $42(91.3)$ & $4(8.7)$ & \\
\hline \multicolumn{4}{|l|}{ Own health perception } \\
\hline Bad & $2(40.0)$ & $3(60.0)$ & \multirow{4}{*}{$<0.01$} \\
\hline Regular & $14(93.3)$ & $1(6.7)$ & \\
\hline Good & $17(89.5)$ & $2(10.5)$ & \\
\hline Very good & $15(100)$ & $0(0)$ & \\
\hline \multicolumn{4}{|l|}{ Fear that the worst will happen } \\
\hline Yes & $33(86.8)$ & $5(13.2)$ & \multirow{2}{*}{0.66} \\
\hline No & $15(93.8)$ & $1(6.3)$ & \\
\hline \multicolumn{4}{|l|}{ Disheartened regarding the future } \\
\hline Yes & $31(62.0)$ & $6(100.0)$ & \multirow{2}{*}{0.09} \\
\hline No & $19(38.0)$ & $0(0.0)$ & \\
\hline \multicolumn{4}{|l|}{ Has already had psychiatric treatment } \\
\hline Yes & $9(81.8)$ & $2(18.2)$ & \multirow{2}{*}{0.59} \\
\hline No & $39(90.7)$ & $4(9.3)$ & \\
\hline \multicolumn{4}{|l|}{ Has had psychological treatment } \\
\hline Yes & $24(82.8)$ & $5(17.2)$ & \multirow{2}{*}{0.20} \\
\hline No & $24(96.0)$ & $1(4 \%)$ & \\
\hline \multicolumn{4}{|l|}{ Has had neurological treatment } \\
\hline Yes & $8(100)$ & $0(0.0)$ & \multirow{2}{*}{0.57} \\
\hline No & $40(87.0)$ & $6(13.0)$ & \\
\hline \multicolumn{4}{|l|}{ Did you use any mental health service during the pandemic } \\
\hline Yes & $16(80.0)$ & $4(20.0)$ & \multirow{2}{*}{0.17} \\
\hline No & $32(94.1)$ & $2(5.9)$ & \\
\hline \multicolumn{4}{|l|}{ Use of medication } \\
\hline Yes & $15(71.4)$ & $6(28.6)$ & \multirow{2}{*}{$<0.01$} \\
\hline No & $33(100)$ & $0(0.0)$ & \\
\hline
\end{tabular}

p $<0.05$ considered significant. Source: Research data (2020).

Isolation and social distancing associated with fear, anxiety, low resilience and psychological distress are factors related to the emergence or exacerbation of suicidal thoughts and suicide, especially among people with a history of psychiatric disorders (Hao et al., 2020; Sher, 2020). A study conducted in Chongqing, China, during the peak of the pandemic, reported a significantly higher prevalence of depressive symptoms, suicidal thought and anger in psychiatric patients (Hao et al., 2020). Among the risk factors for suicide, the WHO cites mental disorders, hopelessness, chronic pain, alcohol abuse, the "feeling" of isolation and lack of social support, and disasters, wars and conflicts (WHO, 2014). Another study, conducted with students from Lima-Peru in 2015, reported $22.0 \%$ of suicidal thoughts and $11.0 \%$ of suicide attempts in the sample. Among the risk factors for these attempts, the authors cited: female gender, depression and distress (Perales et al., 2019). These risk factors are part of the current pandemic context and are present in the daily lives of students and in the data from this research. 
The COVID-19 pandemic is associated to mental alterations and complications (WHO, 2020) and, in this sense, research and follow-up on the neurological, psycho-emotional and psychiatric consequences of COVID-19 are necessary to check for the tropism of the virus in the nervous system, in addition to the neuropsychiatric and mental impacts and the respective risk and protective factors.

The nature of the problem also requires studies that go beyond investigating the impact, detecting changes in mental balance and monitoring the most common psychiatric disorders to assist in decision making regarding social support and health service access strategies, support, prevention, posvention and follow-up (Varatharaj et al., 2020).

Mental health results from complex connections between internal and external factors, including the ability to face new challenges, associated with the perception of reality and the psychopathological history. In addition to the absence of wellconceived and classified disorders, therefore, there is the self-perception of subjective well-being and the individual's ability to (re)adjust. As such, previous experiences, the integration of resources and the offer of effective social support can prevent several unfavorable consequences to life.

\subsection{Coping Strategies}

Students used different strategies and resources to take care of themselves and their feelings and emotions during social isolation. Given their availability and choices, they used different practices and therapies already known to them and offered in a face-to-face way before the pandemic, but which were made available on virtual platforms in the current context. Before the pandemic, the most used integrative practices for health care were Auriculotherapy, Yoga and Meditation. Table 10 shows all the complementary therapies cited by the participants. The practices that prevailed were offered in many extension projects of the university aimed at the holistic care of the academic community.

During the pandemic, integrative practices that adapted to digital platforms were able to gather students in search of self-care. Meditation, Yoga and Integrative Community Therapy (ICT) were useful therapeutic resources during social isolation, as they offered moments of relaxation, self-knowledge and shared listening to problems. During this pandemic, the team of the UFPB's NeuroConnections Project offered virtuais meetings for ICT (Carneiro et al., 2020), Yoga, Reike, ThethaHealing experiences, Nonviolent Communication (CNV), and a lecture on Meditation and Neurosciences. And this could explain the results in Table 10 . 
Table 10 - Integrative and complementary practices, holistic therapies, used during and before social isolation to improve wellbeing and mental health care $(\mathrm{N}=56)$.

\begin{tabular}{|c|c|c|c|c|}
\hline \multirow[t]{2}{*}{ INTEGRATIVE PRACTICES } & \multicolumn{2}{|c|}{$\begin{array}{c}\text { DURING } \\
\text { ISOLATION }\end{array}$} & \multicolumn{2}{|c|}{$\begin{array}{c}\text { BEFORE } \\
\text { ISOLATION }\end{array}$} \\
\hline & $\mathbf{N}$ & $\%$ & $\mathbf{N}$ & $\%$ \\
\hline Meditation & 27 & 48.2 & 18 & 32.1 \\
\hline Yoga & 17 & 30.4 & 19 & 33.9 \\
\hline Integrative Community Therapy (ICT) & 13 & 23.2 & 12 & 21.4 \\
\hline Auriculotherapy & 11 & 19.6 & 30 & 53.6 \\
\hline ThetaHealing & 06 & 10.7 & 03 & 5.4 \\
\hline Music therapy & 06 & 10.7 & 03 & 5.4 \\
\hline Hypnosis & 04 & 7.1 & 06 & 10.7 \\
\hline Aromatherapy & 03 & 5.4 & 07 & 12.5 \\
\hline Reiki & 02 & 3.6 & 07 & 12.5 \\
\hline Floral Therapy & 02 & 3.6 & 01 & 1.8 \\
\hline Art therapy & 01 & 1.8 & 01 & 1.8 \\
\hline Clay therapy & 01 & 1.8 & 04 & 7.1 \\
\hline Biodanza & 01 & 1.8 & 03 & 5.4 \\
\hline Chromotherapy & 01 & 1.8 & 01 & 1.8 \\
\hline Homeopathy & 01 & 1.8 & 07 & 12.5 \\
\hline Cupping Therapy & 00 & 0.0 & 03 & 5.4 \\
\hline Chiropractic & 00 & 0.0 & 02 & 3.6 \\
\hline Scalp acupuncture & 00 & 0.0 & 01 & 1.8 \\
\hline Moxibustion & 00 & 0.0 & 01 & 1.8 \\
\hline No Therapy & 12 & 21.4 & 05 & 8.9 \\
\hline
\end{tabular}

Source: Research data.

Table 10 reveals the decrease in the use of Traditional Chinese Medicine (TCM) therapies during the period of social isolation and the increased access to collective therapies with the possibility of remote participation.

Other resources were cited as forms of self-care and investment in well-being and mental health. Among them, the following stand out: music $(85.7 \%)$, conversation with friends $(78.6 \%)$, conversation with relatives $(57.1 \%)$, singing $(50.0 \%)$, dancing $(42.9 \%)$, online therapies $(39.3 \%)$, online messages on coping methods (30.4\%), writing (26.8\%), poetry books $(16.1 \%)$ and self-help messages $(14.3 \%)$.

Finding different ways to solve problems and seeking support, through conversations with family and friends and online therapies, for example, suggest a search for social support, which is indispensable in this atypical and stressful historical moment. Access to books on mental health, online messages on coping methods and self-help in mental health have been reported by the Wuhan doctors and nurses as ways to protect mental health and improve the self-perception of health (Kang et al., 2020). Recreational activities such as reading, TV series, and games were associated with low scores on stress and anxiety scales among students in Bangladesh (Khan et al., 2020). 
This first phase of the work, focused on local diagnosis, focused on young university students, many with a psychopathological history, dysfunctional thoughts, and diverse possibilities for repercussion on their emotions, behaviors, and learning. The students of the researched group used different strategies to seek self-care and promote well-being and mental health. Among these, holistic therapies stand out, which were adapted to virtual platforms and helped many young people face the pandemic during the period of social isolation. The search for and implementation of therapies and other resources are positive indicators, as they reveal the students' autonomy and personal responsibility towards their health and self-care; as such, it reduces personal vulnerability.

The study showed many protective factors for mental health and against suicide, such as the search for support, social integration in collective therapy activities and community involvement.

\subsection{Research Advantages and Limitations}

The proposed research explored the effects of the pandemic during social isolation and the coping strategies of participants from an academic community. It is worth noting that one of the strengths of the work was the adherence of the issues to the lived context. Among the advantages are the low cost and speed in obtaining the data. However, the main limitation of this study was the lack of adherence of the students, which compromised the statistical quality and prevented the generalization of results, but it revealed the mental suffering experienced by several of these young people, and it may express the reality of many members of the target population, which will have to be confirmed in other studies for the territorial diagnosis.

Because of the pandemic and the protective measures involved, the best alternative was to apply an online questionnaire and take advantage of the agility in the application and tabulation of data, the greater reach of respondents and the low cost. However, this method has many disadvantages: its impersonal nature, the lack of access to information and communication technology (ICT) of the target audience and, in the current context, the large number of survey questionnaires received by students on different digital platforms, which leads to a lack of interest in participating in "yet another survey". In addition, many students have joined online courses and subjects, and it seems that it was difficult to reconcile so many external and internal demands. In addition to the disadvantages cited, there may be some personal vulnerability and lack of motivation to provide data without the prospect of immediate action to assist in managing the psycho-emotional difficulties shared in the study.

\section{Final Considerations}

The COVID-19 pandemic has multiple facets and implications for various aspects of life, including occupational and psycho-emotional aspects. In Brazil, as in other countries, the coronavirus outbreak will pass, but its immediate and late impacts will be revealed through global, national and local research. The neurological, psychological and psychiatric alterations, dimensions that are still "invisible" and evolving slowly and progressively, nourished by isolation and social distancing, by loss, by catastrophic images and news, are still in the waiting room, waiting for their turn. Will they be the next focus of attention?

Faced with a historical fight against COVID-19, with consequences that are still immeasurable, prevalence studies on psychological, neurological and psychiatric alterations can shed light on the subject and the consequent need for public policies to manage the health of the most vulnerable and the population in general in an integrated and integral way, considering their occupations and the socio-cultural and economic context in which they find themselves.

Considering the research data and the need to contextualize and integrate biopsychosocial and spiritual man in his historical, social, political, and relational time-space, we suggest that prevalence studies in the area of mental health should 
observe human beings and their singularities within a holistic concept. From this perspective, one can see that self-perception, pathological history and social support are part of the emotional balance and can represent protective or risk factors related to well-being. As for the questionnaires, the screening scores must be exceeded in order to verify the overlap of symptoms and the cognitive and predictive connections of the items in the questionnaires selected for the research. In addition to the validated questionnaire scores, therefore, there are the factors of self-perception, subjective well-being, autonomy, social relations, local history and individual and collective coping strategies of the population under analysis.

\section{References}

Brandtner, M., \& Bardagi, M. (2009). Sintomatologia de depressão e ansiedade em estudantes de uma universidade privada do Rio Grande do Sul. Gerais: Revista Interinstitucional de Psicologia, 2(2), 81-91.

Brewin, C. R., Andrews, B., \& Valentine, J. D. (2000). Meta-analysis of risk factors for posttraumatic stress disorder in trauma-exposed adults. Journal of Consulting and Clinical Psychology, 68(5), 748.

Cao, W., Fang, Z., Hou, G., Han, M., Xu, X., Dong, J., \& Zheng, J. (2020). The psychological impact of the COVID-19 epidemic on college students in China. Psychiatry Research, 287, 112934. 10.1016/j.psychres.2020.112934

Carneiro, A. L. B., Ramos, S. C. D. S., Ribeiro, R. M., Melo, C. D. M. B. D., Melo, M. N. A. D., Aguiar, P. K. F. D., \& Falcão, P. B. L. (2020). Terapia Comunitária Integrativa em Tempos de Pandemia: Encontros, encantos, (con)vivências e partilhas que transcendem as telas. Research, Society and Development, 9(11), e2869119785. doi:10.33448/rsd-v9i11.9785

Cunha, J. A. (2017). Manual da Versão em Português das Escalas Beck: Pearson Clinical Brasil.

Gagliato, M. (2020). Guia Preliminar: como lidar com os aspectos psicossociais e de saúde mental referente ao surto de COVID-19. Versão, 1.5, 2020-03

Goldmann, E., \& Galea, S. (2014). Mental Health Consequences of Disasters. Annual Review of Public Health, 35(1), 169-183. 10.1146/annurev-publhealth032013-182435

Hao, F., Tan, W., Jiang, L., Zhang, L., Zhao, X., Zou, Y., \& Tam, W. (2020). Do psychiatric patients experience more psychiatric symptoms during COVID19 pandemic and lockdown? A case-control study with service and research implications for immunopsychiatry. Brain, Behavior, and Immunity, 87, 100-106. 10.1016/j.bbi.2020.04.069

Holmes, E. A., O'Connor, R. C., Perry, V. H., Tracey, I., Wessely, S., Arseneault, L., \& Bullmore, E. (2020). Multidisciplinary research priorities for the COVID-19 pandemic: a call for action for mental health science. The Lancet Psychiatry, 7(6), 547-560. 10.1016/s2215-0366(20)30168-1

Kang, L., Ma, S., Chen, M., Yang, J., Wang, Y., Li, R., \& Liu, Z. (2020). Impact on mental health and perceptions of psychological care among medical and nursing staff in Wuhan during the 2019 novel coronavirus disease outbreak: A cross-sectional study. Brain, Behavior, and Immunity, 87, 11-17. 10.1016/j.bbi.2020.03.028

Khan, A. H., Sultana, M. S., Hossain, S., Hasan, M. T., Ahmed, H. U., \& Sikder, M. T. (2020). The impact of COVID-19 pandemic on mental health \& wellbeing among home-quarantined Bangladeshi students: A cross-sectional pilot study. https://doi.org/10.31234/osf.io/97s5r

Naguy, A., Moodliar-Rensburg, S., \& Alamiri, B. (2020). Coronaphobia and chronophobia - A psychiatric perspective. Asian Journal of Psychiatry, 51, s. 102050. 10.1016/j.ajp.2020.102050

Ornell, F., Schuch, J. B., Sordi, A. O., \& Kessler, F. H. P. (2020). Pandemia de medo e COVID-19: impacto na saúde mental e possíveis estratégicas. Revista Debates in Psychiatry.

Perales, A. et al. (2019). Prevalencia y factores asociados a conducta suicida en estudiantes de la Universidad Nacional Mayor de San Marcos, Lima-Perú. Anales de la Facultad de Medicina, 80 (1), s. 28-33. 10.15381/anales. v80i1.15865

Pereira, A. S., Shitsuka, D. M., Parreira, F. J., \& Shitsuka, R. (2018). Metodologia da Pesquisa Científica (UAB/NTE/UFSM Ed.). Santa Maria. https://repositorio.ufsm.br/bitstream/handle/1/15824/Lic_Computacao_Metodologia-Pesquisa-Cientifica.pdf?sequence=1

Organização Mundial de Saúde. (2000). Prevenção do Suicídio: um manual para profissionais da saúde em atenção primária. Genebra. https://www.who.int/mental_health/prevention/suicide/en/suicideprev_phc_port.pdf

Rubin, G. J., \& Wessely, S. (2020). The psychological effects of quarantining a city. BMJ, 368. s. m313. 10.1136/bmj.m313

Sher, L. (2020). The impact of the COVID-19 pandemic on suicide rates. QJM: An International Journal of Medicine, 113(10), 707-712. 10.1093/qjmed/hcaa202

Stella, F., \& Sommerhalder, A. (2000). Sintomas Mentais e Consumo de Álcool por Estudantes da UNESP, Instituto de Biociências de Rio Claro, SP. Educação: Teoria e Prática, 8(14/15). http://hdl.handle.net/11449/107464

Stopa, S. R., Malta, D. C., Oliveira, M. M. D., Lopes, C. D. S., Menezes, P. R., \& Kinoshita, R. T. (2015). Prevalência do autorrelato de depressão no Brasil: resultados da Pesquisa Nacional de Saúde, 2013. Revista Brasileira de Epidemiologia, 18 (suppl 2), s. 170-180. 10.1590/1980-5497201500060015 
Research, Society and Development, v. 10, n. 1, e59110112144, 2021 (CC BY 4.0) | ISSN 2525-3409 | DOI: http://dx.doi.org/10.33448/rsd-v10i1.12144

Talevi, D., Socci, V., Carai, M., Carnaghi, G., Faleri, S., Trebbi, E., \& Pacitti, F. (2020). Mental health outcomes of the CoViD-19 pandemic. Rivista di Psichiatria, 55(3), 137-144. 10.1708/3382.33569

Tang, W., Hu, T., Hu, B., Jin, C., Wang, G., Xie, C., \& Xu, J. (2020). Prevalence and correlates of PTSD and depressive symptoms one month after the outbreak of the COVID-19 epidemic in a sample of home-quarantined Chinese university students. Journal of Affective Disorders, 274, 1-7. 10.1016/j.jad.2020.05.009

Tortella-Feliu, M., Fullana, M. A., Pérez-Vigil, A., Torres, X., Chamorro, J., Littarelli, S. A., \& González-Parra, J. A. (2019). Risk factors for posttraumatic stress disorder: An umbrella review of systematic reviews and meta-analyses. Neuroscience \& Biobehavioral Reviews, 107, 154-165.

Varatharaj, A., Thomas, N., Ellul, M. A., Davies, N. W. S., Pollak, T. A., Tenorio, E. L., \& Plant, G. (2020). Neurological and neuropsychiatric complications of COVID-19 in 153 patients: a UK-wide surveillance study. The Lancet Psychiatry, 7(10), 875-882. 10.1016/s2215-0366(20)30287-x

Vieira, S., \& Hossne, W. S. (2020). Metodologia Científica para a Área da Saúde (2 ed.): GEN / Grupo Editorial Nacional S.A.

Wang, S., Wen, X., Dong, Y., Liu, B., \& Cui, M. (2020). Psychological Influence of Coronovirus Disease 2019 (COVID-19) Pandemic on the General Public, Medical Workers, and Patients With Mental Disorders and its Countermeasures. Psychosomatics. 10.1016/j.psym.2020.05.005

World Health $\quad$ Organization. (2014). Preventing $\quad$ suicide: $\quad$ A $\quad$ global imperative. $\quad$ (9241564776). https://apps.who.int/iris/bitstream/handle/10665/131056/9789241564779-ger.pdf

World Health Organization. (2020). The impact of COVID-19 on mental, neurological and substance use services (W. H. Organization Ed.). Geneva: World Health Organization. Licence: CC BY-NC-SA 3.0 IGO. https://www.who.int/publications-detail-redirect/978924012455

World Health Organization. (2017). Depression and Other Common Mental Disorders: Global Health Estimates. s. Geneva. Licence: CC BY-NC-SA 3.0 IGO. https://www.who.int/mental_health/management/depression/prevalence_global_health_estimates/en/ 